\title{
Contents / Contenidos
}

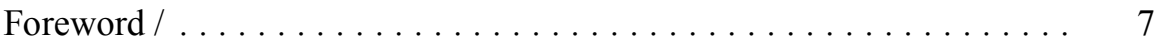

Prefacio .............................. 10

Part 1 / Parte 1

An Overview of Digital Libraries in Sustainable

Development / Una Visión General de Bibliotecas Digitales en el Desarrollo Sostenible

\section{Lynne M. Rudasill}

Open Access and Development . . . . . . . . . . . . . . . 15

El acceso abierto y el desarrollo. . . . . . . . . . . . . . . 24

María E. Dorta-Duque and Dominique Babini

Open Access Digital Repositories from Latin America and the Caribbean as Resources for Social Science Libraries. . . . . . . . . . . 35

Repositorios Digitales de Acceso Abierto en América Latina y

el Caribe Como Recursos Para las Bibliotecas de Ciencias Sociales. . . . .

Part 2 / Parte 2

Digital Library Development in Cuba /

Biblioteca Digital Desarrollo en Cuba

\section{Iroel Sánchez}

The Societal Use of Technology in the Knowledge Society: the Cuban Experience . . . . . . . . . . . . . . . . . . . . . . . .

El Uso Social de la Tecnología en la Sociedad del Conocimiento: la Experiencia Cubana. . . . . . . . . . . . . . . . . . . . . .

Ricardo Casate Fernández and José Antonio Senso Ruiz

The Landscape of Open Access Journals in Cuba: the Strategy and Model for its Development . . . . . . . . . . . . . . . . . . . .

El Panorama de las Revistas de Acceso Abierto en Cuba: 
Dinorah Sánchez Remón and Nancy Sánchez Tarragó

Repository for Doctoral Thesis from the National Health System of Cuba. . . . . . . . . . . . . . . . . . . . . . . . . . 137

Repositorio de Tesis Doctorales para el Sistema Nacional de Salud de Cuba . . . . . . . . . . . . . . . . . . . . . . . 15

Lenay Barceló Soto and Liudmila Báez Sánchez

The Repository of the Cuban Press: A Feasibility Study for a

New Project . . . . . . . . . . . . . . . . . . . . . . . . 165

El Repositorio de la Prensa Cubana: Un Proyecto en Ciernes o Estudio de Factibilidad . . . . . . . . . . . . . . . . . . . . . . 180

Ascanio Alvarez Alvarez

The Interbanking Portal Web Service of the Banking and

Economics Information Center (Cibe) . . . . . . . . . . . . . . . . . . 197

El Portal Interbancario como Servicio Web del Centro de Información Bancaria y Económica (Cibe) . . . . . . . . . . . . . . . . . . . . . . 210

Raul G. Torricella Morales, Francisco Lee Tenorio and

Jorge Luis Lopez Presmanes

Socialization of Knowledge: Open Access and Proprietary . . . . . . . . 225

Socialización del Conocimiento: Acceso Abierto y Privativo. . . . . . . . 247

\section{Part 3 / Parte 3}

Conclusion / Conclusión

\section{Liz Cooper and JoAnn Jacoby}

Information Needs and Research Practices of Graduate Students

in the Master's in Development Practice Program. . . . . . . . . . . . . . 275

Necesidades de Información y Prácticas de Investigación de Estudiantes

Graduados en el Programa de Master en Practica del Desarrollo . . . . . . . 289

Tiffini A. Travis

Using Social Media for Open Access: Best Practices for

Dissemination of Digital Information . . . . . . . . . . . . . . . . 305

Uso de Medios de Comunicación Social para el Acceso Abierto: Mejores Prácticas para la Difusión de la Información Digital . . . . . . . . . . 319

About the Authors / Acerca de los Autores. . . . . . . . . . . . . . . . . . 337 